\title{
Isolation and Characterization of Polymeric Galloyl-Ester- Degrading Bacteria from a Tannery Discharge Place
}

\author{
A.R. Franco ${ }^{1}$, C.S.C. Calheiros ${ }^{1}$, C.C. Pacheco ${ }^{2}$, P. De Marco², \\ C.M. Manaia ${ }^{1}$ and P.M.L. Castro ${ }^{1}$ \\ (1) Escola Superior de Biotecnologia, Universidade Católica Portuguesa, R. Dr. António Bernardino de Almeida, 4200-072 Porto, Portugal \\ (2) Instituto de Biologia Molecular e Celular, Universidade do Porto, R. Campo Alegre, 823, 4150-180 Porto, Portugal
}

\begin{abstract}
The culturable bacteria colonizing the rhizosphere of plants growing in the area of discharge of a tannery effluent were characterized. Relative proportions of aerobic, denitrifying, and sulfate-reducing bacteria were determined in the rhizosphere of Typha latifolia, Canna indica, and Phragmites australis. Aerobic bacteria were observed to be the most abundant group in the rhizosphere, and plant type did not seem to influence the abundance of the bacterial types analyzed. To isolate bacteria able to degrade polyphenols used in the tannery industry, enrichments were conducted under different conditions. Bacterial cultures were enriched with individual polyphenols (tannins Tara, Quebracho, or Mimosa) or with an undefined mixture of tannins present in the tannery effluent as carbon source. Cultures enriched with the effluent or Tara tannin were able to degrade tannic acid. Six bacterial isolates purified from these mixed cultures were able to use tannic acid as a sole carbon source in axenic culture. On the basis of $16 \mathrm{~S}$ ribosomal DNA sequence analysis, these isolates were closely related to organisms belonging to the taxa Serratia, Stenotrophomonas maltophilia, Klebsiella oxytoca, Herbaspirillum chlorophenolicum, and Pseudomonas putida.
\end{abstract}

\section{Introduction}

Wastewaters from natural tanneries contain high levels of water-soluble polyphenols, which are increasingly used in post-tanning operations as chromium substitutes [6]. Vegetation plays an important role in wastewater treat-

Correspondence to: P.M.L. Castro; E-mail: plcastro@esb.ucp.pt ment, as it provides a substrate and a habitat for microorganisms within the soil area [4]. The use of vegetation both to remediate contaminated fields and to treat wastewaters, known as phytoremediation, is an emergent technology that offers a low-cost and effective alternative to other treatment systems $[22,23]$.

The rhizosphere, the region surrounding the plant root, is a dynamic environment, characterized by a high turnover of nutrients promoted by soil bacteria. In the past few years, biodegradation in the rhizosphere has attracted widespread interest because of the role of the active microbial community around the roots in the biodegradation of organic contaminants. Bacterial diversity in the rhizosphere and root system is influenced, among other factors, by the plant species and bacterial responses to root exudates [7]. Soil rhizosphere microbial communities comprise a diversity of bacteria and archaea, either aerobic or anaerobic, such as methanogens or sulfate reducers [24]. Microbial activity is a key factor in the proper functioning and maintenance of a phytoremediation system, as it is responsible for the removal of organic matter [11].

Tannins, hydrolyzable or condensed, are naturally occurring polyphenols, being abundant in leaves, fruits, and some seeds as well as in wood and bark. Hydrolyzable tannins are made up of esters of gallic acid (gallotannins) or hexahydroxydiphenic acid (ellagitannins) and a sugar core, usually glucose. Condensed tannins, also named polymeric proanthocyanidins, are composed of flavonoid units and are usually more abundant in tree bark than hydrolyzable tannins. Tannins are widely used in the tannery sector, and its presence in wastewaters derived from leather industries can have environmental adverse effects. Tannins are known for inhibiting the growth of microorganisms, being recalcitrant to biodegradation [3]. However, 
bacteria capable of degrading tannins have been isolated from diverse sources, such as sewage sludge or the gastrointestinal tract of ruminants $[2,12,16]$.

In this study, culturable bacterial populations from the rhizosphere of plants colonizing a tannery discharge field site were characterized. In addition, bacterial cultures able to degrade polyphenols used in the tanning process were enriched and isolated, using soil from the discharge site. Enrichment cultures and bacterial isolates were subsequently characterized and their ability for polyphenol degradation was assessed.

\section{Materials and Methods}

\section{Site Description}

Sample Collection. Soil and plants were sampled between January and June 2003, using the procedure described by Dunfield and Germida [7]. Plants and soil were collected at an industrial discharge site (Northern Portugal), within an area of ca. $10 \mathrm{~m}^{2}$ with a slope of ca. $1 \%$, at depths of 7 and $22 \mathrm{~cm}$. Samples were collected using a trowel, placed in a sterile plastic bag, and transported to the laboratory, where they were processed within $2 \mathrm{~h}$ from collection.

Soil Rhizosphere and Root Interior Bacteria Enumeration. A 5-g sample of soil was suspended in $95 \mathrm{~mL}$ of Ringer solution and was shaken for $20 \mathrm{~min}$ at room temperature. Appropriate dilutions of the suspension were spread onto three different media for total aerobic, denitrifying, or sulfate-reducing bacterial enumeration: (1) $10 \%$ plate count agar; (2) nitrate agar medium (NM; $5 \mathrm{~g} \mathrm{~L}^{-1}$ peptone, $3 \mathrm{~g} \mathrm{~L}^{-1}$ beef extract, $1 \mathrm{~g} \mathrm{~L}^{-1} \mathrm{KNO}_{3}$, and $15 \mathrm{~g} \mathrm{~L}^{-1}$ agar) [18]; and (3) lactate agar medium (LM; $12 \mathrm{~g} \mathrm{~L}^{-1}$ sodium lactate, $4.5 \mathrm{~g} \mathrm{~L}^{-1} \mathrm{NaSO}_{4}, 0.06 \mathrm{~g} \mathrm{~L}^{-1} \mathrm{CaCl}_{2} \cdot 2 \mathrm{H}_{2} \mathrm{O}$, $0.3 \mathrm{~g} \mathrm{~L}^{-1}$ sodium citrate, $1 \mathrm{~g} \mathrm{~L}^{-1} \mathrm{NH}_{4} \mathrm{Cl}, 0.5 \mathrm{~g} \mathrm{~L}^{-1} \mathrm{KH}_{2} \mathrm{PO}_{4}$, $2 \mathrm{~g} \mathrm{~L}^{-1} \mathrm{MgSO}_{4} \cdot 7 \mathrm{H}_{2} \mathrm{O}, 1 \mathrm{~g} \mathrm{~L}^{-1}$ yeast extract, $12 \mathrm{~g} \mathrm{~L}^{-1}$ agar, $0.08 \mathrm{~mL} \mathrm{~L}^{-1} \mathrm{FeSO}_{4}$ solution, $10 \mathrm{~mL} \mathrm{~L}^{-1}$ of a reduction solution at $0.015 \mathrm{~g} \mathrm{~mL}^{-1}$ sodium dithionite, $0.010 \mathrm{~g} \mathrm{~mL}^{-1}$ ascorbic acid) [25]. Root samples (5 g) were washed by shaking at $200 \mathrm{rpm}$ in $1.05 \%(\mathrm{v} / \mathrm{v})$ sodium hypochlorite solution for $20 \mathrm{~min}$ [7]. The roots were rinsed four times with $200 \mathrm{~mL}$ of Ringer solution, chopped into $<1-\mathrm{mm}$ sections, and triturated with a sterile mortar and pestle in $95 \mathrm{~mL}$ of Ringer solution (1:10), and inoculated onto the media described above. Plates were incubated at $25^{\circ} \mathrm{C}$ for 3 days for total aerobic bacteria, 15 days for denitrifying bacteria, and 30 days for sulfate-reducing bacteria. Pieces of sterile root were incubated similarly to confirm that bacterial counts were relative to the root interior.

Enrichment Cultures. Aerobic enrichment cultures were prepared by suspending $2 \mathrm{~g}$ of soil from the discharge site in different culture media. Soil samples were added to $50 \mathrm{~mL}$ of effluent (Table 1) or minimal salts medium (MM) [5] supplemented with $0.5 \mathrm{~g} \mathrm{~L}^{-1}$ of one of the tannins, Tara, Quebracho (UNITÁN, Buenos Aires, Argentina), or Mimosa (TANAC S.A., Montenegro, RS, Brazil). Tara tannin is a gallotannin and Mimosa and Quebracho are condensed tannins. Cultures were incubated at $25^{\circ} \mathrm{C}$ for 7 days and were refreshed weekly for 3 months by transferring $10 \mathrm{~mL}$ of the culture to $40 \mathrm{~mL}$ of fresh mineral medium or effluent. Cultures enriched with effluent and Tara tannin, later designated as cultures $\mathrm{E}$ and $\mathrm{T}$, were selected for further degradation studies. Anaerobic enrichment cultures under denitrifying conditions were prepared by adding $2 \mathrm{~g}$ of soil to $100 \mathrm{~mL}$ of a mixture of liquid effluent and $\mathrm{MM}$ with $1 \mathrm{~g} \mathrm{~L}^{-1}$ of $\mathrm{KNO}_{3}(50: 50 \mathrm{v} / \mathrm{v})$ and $100 \mathrm{~mL}$ of $\mathrm{MM}$ with $1 \mathrm{~g} \mathrm{~L}^{-1}$ of $\mathrm{KNO}_{3}$, supplemented with $0.5 \mathrm{~g} \mathrm{~L}^{-1}$ of one of the tannins in $125-\mathrm{mL}$ serum bottles with butyl rubber stoppers and aluminum crimp seals, under a headspace of $\mathrm{N}_{2}$, and incubated at $25^{\circ} \mathrm{C}$ with shaking. Cultures were refreshed at 15 -day intervals by transferring $10 \mathrm{~mL}$ of the culture to $90 \mathrm{~mL}$ of fresh medium. Anaerobic enrichment cultures under sulfate-reducing conditions were prepared, using lactate medium, as described for denitrifying cultures. Cultures were refreshed at 30-day intervals by transferring $10 \mathrm{~mL}$ of the culture to $90 \mathrm{~mL}$ of fresh medium. Anaerobic enrichment cultures were maintained for

Table 1. Physical-chemical characterization of the tannery effluent

\begin{tabular}{llr}
\hline Parameter & Analytical method ${ }^{a}$ & Mean \pm SD (min-max) \\
\hline $\mathrm{pH}$ & SMEWW, 4500-H $\mathrm{H}^{+}$, B; electrometric method & $6.0 \pm 0.9(4.6-8.1)$ \\
$\mathrm{COD}\left(\mathrm{mg} \mathrm{O}_{2} \mathrm{~L}^{-1}\right)$ & SMEWW, 5220-CQO, D; closed reflux colorimetric method & $2000 \pm 507(1400-3000)$ \\
$\mathrm{BOD}\left(\mathrm{mg} \mathrm{L}^{-1}\right)$ & SMEWW, 5210-B; 5-day BOD test & $1019 \pm 67(980-1170)$ \\
Sulfates $\left(\mathrm{mg} \mathrm{SO}_{4}^{2-} \mathrm{L}^{-1}\right)$ & AOACOM, 937.57; turbidimetric method & $877 \pm 177(600-1200)$ \\
Nitrates $\left(\mathrm{mg} \mathrm{NO}_{3}^{-} \mathrm{NL}^{-1}\right)$ & SMEWW, 4500-NO & $38 \pm 4(36-44)$ \\
Nitrites $\left(\mathrm{mg} \mathrm{NO}_{2}^{-} \mathrm{NL}^{-1}\right)$ & SMEW nitrate electrode method & $150 \pm 43(100-220)$ \\
Conductivity $\left(\mathrm{cm} \mathrm{s}^{-1}\right)$ & SMEWW, 2510-B; laboratory method & $10 \pm 2(8-13)$ \\
Total suspended solids $\left(\mathrm{mg} \mathrm{total} \mathrm{solids} \mathrm{L}^{-1}\right)$ & SMEWW, 2540-SST, D; total suspended solids dried at 105 ${ }^{\circ} \mathrm{C}$ & $70 \pm 20(20-100)$ \\
Polyphenols $\left(\mathrm{mg} \mathrm{L}^{-1}\right)$ & Folin-Denis method [7] & $105 \pm 36(41-140)$ \\
\hline
\end{tabular}

${ }^{a}$ Unless otherwise stated, determinations were made according to standard procedures [10] and were based on three independent samples. All data represent means $\pm \mathrm{SD}(n=3)$.

COD: Chemical oxygen demand; BOD: Biochemical oxygen demand. 
6 months. All cultures were cryopreserved in minimal medium containing $20 \%$ glycerol $(\mathrm{v} / \mathrm{v})$ at $-70^{\circ} \mathrm{C}$.

Growth in Tannic Acid or Tara Tannin as Single Carbon Source. Cultures pregrown in tannic acid were washed twice with saline solution and inoculated in MM supplemented with $0.5 \mathrm{~g} \mathrm{~L}^{-1}$ of tannic acid (powder, extra pure, $\mathrm{MW}=1701.20 \mathrm{~g} \mathrm{~mol}^{-1}$, Riedel-de Haën, Germany) or Tara tannin. Cultures were incubated at $25^{\circ} \mathrm{C}$ in a shaking incubator at $100 \mathrm{rpm}$. These experiments were prepared in duplicate and an abiotic control was run under the same conditions. Bacterial growth was monitored by measuring the optical density (OD) at $600 \mathrm{~nm}$. Tannic acid or Tara tannin depletion was followed using the Folin-Denis colorimetric and high-performance liquid chromatography (HPLC)-UV methods.

Characterization of Pure Isolates. Bacterial isolates were purified from enrichment cultures by successive streaking onto nutrient agar medium. Isolates were reinoculated into MM containing tannic acid or Tara tannin as carbon source. When growth was observed, samples of the culture were spread onto nutrient agar medium to confirm their purity. Six bacterial isolates, designated as CE1, CE2, and CE3 and CT1, CT2, and CT3, were purified and were further characterized.

Partial nucleotide sequences (664 bp for CE1, $657 \mathrm{bp}$ for CE2, 695 bp for CE3, 695 bp for CT1, 642 bp for $\mathrm{CT} 2$, and $544 \mathrm{bp}$ for CT3) were determined and $16 \mathrm{~S}$ rRNA sequences were obtained from the National Center for Biotechnology Information (NCBI) taxonomy database (http://www.ncbi.nlm.nih.gov/Taxonomy). Sequences have been deposited under GenBank accession numbers AY904044 for CE1, AY702480 for CE2, AY702481 for CE3, AY702479 for CT1, AY702478 for CT2, and AY702477 for CT3. Provisional classification of the isolates was performed by BLAST comparison [1] of partial sequences to the nonredundant NCBI databank (filter: Bacteria).

Polyphenol Analysis. Total polyphenol concentration was determined by a modified Folin-Denis method [8] Briefly, $3.75 \mathrm{~mL}$ of minimal medium was mixed with $0.5 \mathrm{~mL}$ of a diluted sample and $0.25 \mathrm{~mL}$ of FolinDenis reagent; after a 5 -min rest, $0.5 \mathrm{~mL}$ of $20 \%$ sodium carbonate solution was added and the sample was vortexed. After $2 \mathrm{~h}$ of incubation at room temperature, samples were centrifuged at $5000 \mathrm{rpm}$ for 10 min and the absorbance of the supernatant was read at $760 \mathrm{~nm}$. Tannic acid concentration was determined by HPLC-UV [26], using a LiChrospher reverse-phase $\mathrm{C}_{18}$ column $(5 \mu \mathrm{m}$ particle size; $250 \mathrm{~mm} \times 4 \mathrm{~mm}$ I.D., Merck) and an elution gradient with $0.025 \%$ phosphoric acid in water (A) and $0.025 \%$ phosphoric acid in

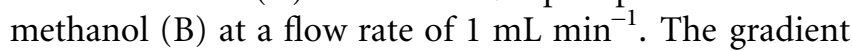

was as follows: B increased from 10 to $64 \%$ at $18 \mathrm{~min}$ to $100 \%$ at $20 \mathrm{~min}$ and returned to $10 \%$ at $22 \mathrm{~min}$. The eluent was monitored simultaneously at wavelengths 254 and $280 \mathrm{~nm}$.

Statistical Analysis. The number of bacterial CFUs was analyzed by ANOVA and means separated using Tukey test at a significance level of 0.05 . Means of aerobic, denitrifying, and sulfate-reducing bacterial groups (between January and June) were compared using Student's $t$-test at a significance level of 0.05.

\section{Results and Discussion}

Characterization of Culturable Bacteria. The abundance and diversity of microbial communities in soil rhizosphere may be influenced by the type and amount of plants and by the climate conditions. Enumeration of aerobic, denitrifying, and sulfate-reducing bacteria was carried out at two different periods, early winter and late spring (January and June 2003), from the rhizosphere and root interior of the most abundant plant species present at a tannery effluent discharge site, namely, Typha latifolia, Canna indica, and Phragmites australis (Table 2). Based on colony morphology, it was possible to distinguish a total of 54 aerobic, 27 denitrifying, and 17 sulfatereducing bacterial types from the root interior and rhizosphere of the three plants studied.

Counts of aerobic and denitrifying bacteria were in the same order of magnitude for all plants analyzed, and higher than those of sulfate reducers. Generally, higher bacterial counts were obtained in June, especially for the aerobic group. Seasonal fluctuations of microbial counts in the rhizosphere and root interior were described in previous studies, where higher bacterial counts were found during the summer period and lower during the winter $[9,19]$. Furthermore, parameters such as humidity and nutrient supply can also play a crucial role, as they influence microbial community growth and diversity between the rhizosphere and root interior [9]. In the present study, data from June also revealed slightly higher counts of culturable aerobic and denitrifying bacteria in the root interior than on the exterior of all plants, although within the same order of magnitude. Differences were not evident in January, when counts on the exterior of the plants were slightly higher. Counts of sulfate-reducing bacteria were very low both in the root interior and in the rhizosphere. The predominance of aerobic bacteria may be associated to the fact that macrophyte-mediated transfer of oxygen to the rhizosphere by leakage from roots increases aerobic degradation of organic matter and nitrification [4]. This constant release of oxygen in the rhizosphere is of particular interest to wastewater treatment in constructed wetlands, with microbial communities playing a major role 


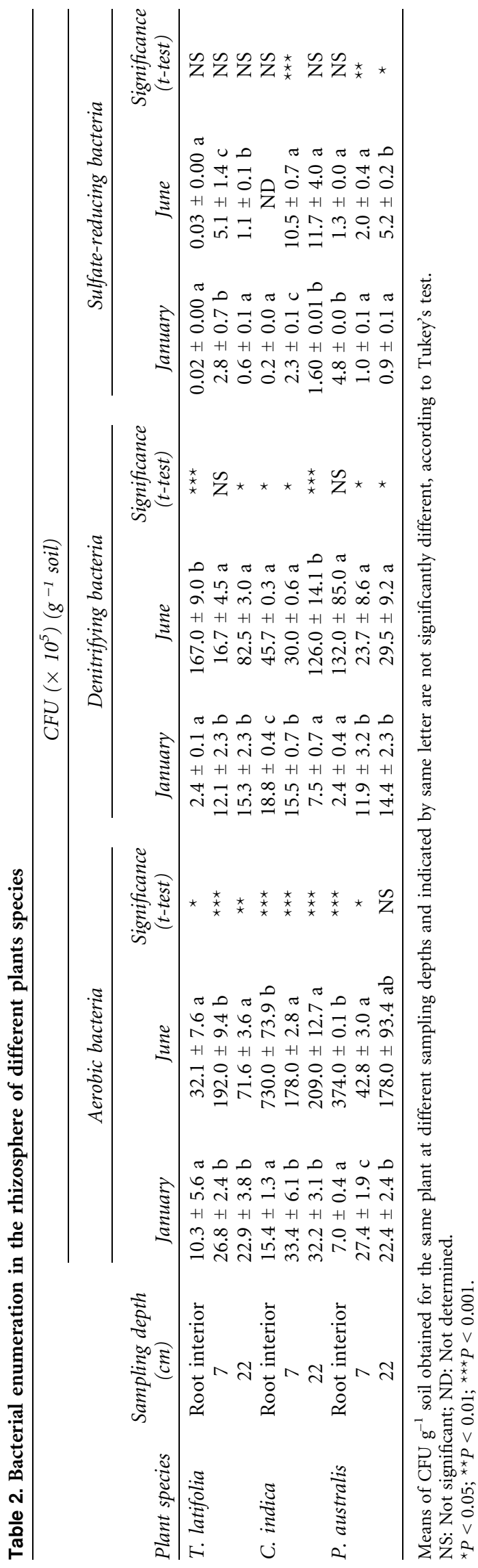

in pollutant degradation. Aerobic processes are more common near roots and rhizoplane, and anaerobic processes, such as denitrification, occur more often in microaerophilic to anoxic zones. Intensive convective gas transport was observed in T. latifolia and $P$. australis [21]. P. australis is the most common plant type used in constructed wetlands, especially due to its high potential productivity [23].

The ratio between aerobic and denitrifying bacteria (Table 3) observed at both sampling times showed the predominance of the first group, regardless of sampling depth. However, this analysis did not allow inferring about the influence of sampling depth and sampling period on the proportion of the different physiological bacterial groups.

Enrichments with Hydrolyzable and Condensed Tannins. Enrichment cultures capable of polyphenol degradation under aerobic, denitrifying, and sulfate reducing conditions were obtained by using soil from the effluent discharge area as inoculum. After 3 months of successive transfers, aerobic cultures designated as $\mathrm{E}$ and $\mathrm{T}$, enriched, respectively, with effluent (wastewater from the tannery) and Tara tannin presented the highest percentage of tannin. Cultures $\mathrm{E}$ and $\mathrm{T}$ were able to degrade 61 and $98 \%$, respectively, of the total polyphenols in the enrichment media used, as determined by the Folin-Denis method. Nevertheless, the same cultures were not able to use the condensed tannins (Quebracho and Mimosa) as a carbon source. Cultures enriched with the condensed tannins Quebracho or Mimosa as carbon sources presented a degradation extent of those polyphenols lower than $20 \%$. These results corroborate information available in the literature, which refer to degradation of condensed tannins by bacterial cultures as difficult, as they are more resistant to microbial attack and more toxic, retarding the rate of decomposition of soil organic matter via inhibition of biodegradative enzymes $[3,20]$. Cultures $\mathrm{E}$ and $\mathrm{T}$ were selected for further degradation studies.

Degradation of Polyphenols by Selected Enrichment Cultures. Degradation studies with tannic acid or Tara tannin as substrate were carried out using enrichment cultures $\mathrm{E}$ and $\mathrm{T}$ (Fig. 1). Cultures were pregrown for $24 \mathrm{~h}$ with the substrate to be tested (tannic acid or Tara tannin), after which they were used as inocula for degradation studies. Both cultures were able to use tannic acid as substrate, using either a commercial tannic acid or Tara tannin. After $30 \mathrm{~h}$, culture $\mathrm{T}$ ceased growth, having degraded ca. $75 \%$ of tannic acid. During the stationary phase, degradation of tannic acid continued, and after $72 \mathrm{~h}$, ca. 95\% had been degraded. Similarly, for culture E, 50\% of tannic acid was degraded until late exponential phase, reaching about ca. $89 \%$ of 
Table 3. Relative proportions of aerobic bacteria over denitrifying and sulfate-reducing bacteria in the rhizosphere of different plant species

\begin{tabular}{|c|c|c|c|c|c|}
\hline \multirow[b]{2}{*}{ Plant species } & \multirow[b]{2}{*}{ Sampling depth $(\mathrm{cm})$} & \multicolumn{2}{|c|}{$A E R / D E N$} & \multicolumn{2}{|c|}{$A E R / S R B$} \\
\hline & & January & June & January & June \\
\hline \multirow[t]{3}{*}{ T. latifolia } & Root interior & 4.3 & 1.9 & 500.0 & 1000.0 \\
\hline & 7 & 2.2 & 11.5 & 9.5 & 37.0 \\
\hline & 22 & 1.5 & 0.7 & 41.7 & 62.5 \\
\hline \multirow[t]{3}{*}{ C. indica } & Root interior & 0.4 & 8.2 & 37.0 & ND \\
\hline & 7 & 1.5 & 0.9 & 41.7 & 62.5 \\
\hline & 22 & 2.2 & 5.9 & 14.9 & 16.9 \\
\hline \multirow[t]{3}{*}{ P. australis } & Root interior & 5.4 & 5.5 & 3.2 & 500.0 \\
\hline & 7 & 2.2 & 5.9 & 14.9 & 16.9 \\
\hline & 22 & 4.3 & 1.7 & 18.5 & 17.9 \\
\hline
\end{tabular}

AER: Aerobic bacterial group; DEN: denitrifying bacterial group; SRB: sulfate-reducing bacterial group; ND: not determined.

degradation after $52 \mathrm{~h}$ of incubation. The degradation of tannic acid during the stationary phase may be due to extracellular tannases involved in the hydrolysis of this tannin [3]. Uninoculated medium, used as an abiotic control, showed that $11 \%$ of tannic acid was degraded during the same time period $(72 \mathrm{~h})$ due to autoxidation, as indicated by the absence of gallic acid release to the medium. Both cultures $\mathrm{T}$ and $\mathrm{E}$ produced gallic acid as a degradation product of tannic acid (Fig. 2). Gallic acid accumulated in the medium and reached concentrations close to that which would be obtained from tannic acid hydrolysis, assuming a stoichiometry of 1 tannic acid:10 gallic acid [15]. Tannins, as tannic acid or gallotannins, are hydrolyzed to gallic acid and glucose by the enzymatic activity of tannases or by nonbiological acid hydrolysis [3]. During the growth period, cultures T and E probably would have assimilated the glucose as a readily available carbon source, explaining why gallic acid remains in the medium [13].

Characterization of Bacterial Isolates. Three bacterial strains, CE1, CE2, and CE3, were isolated
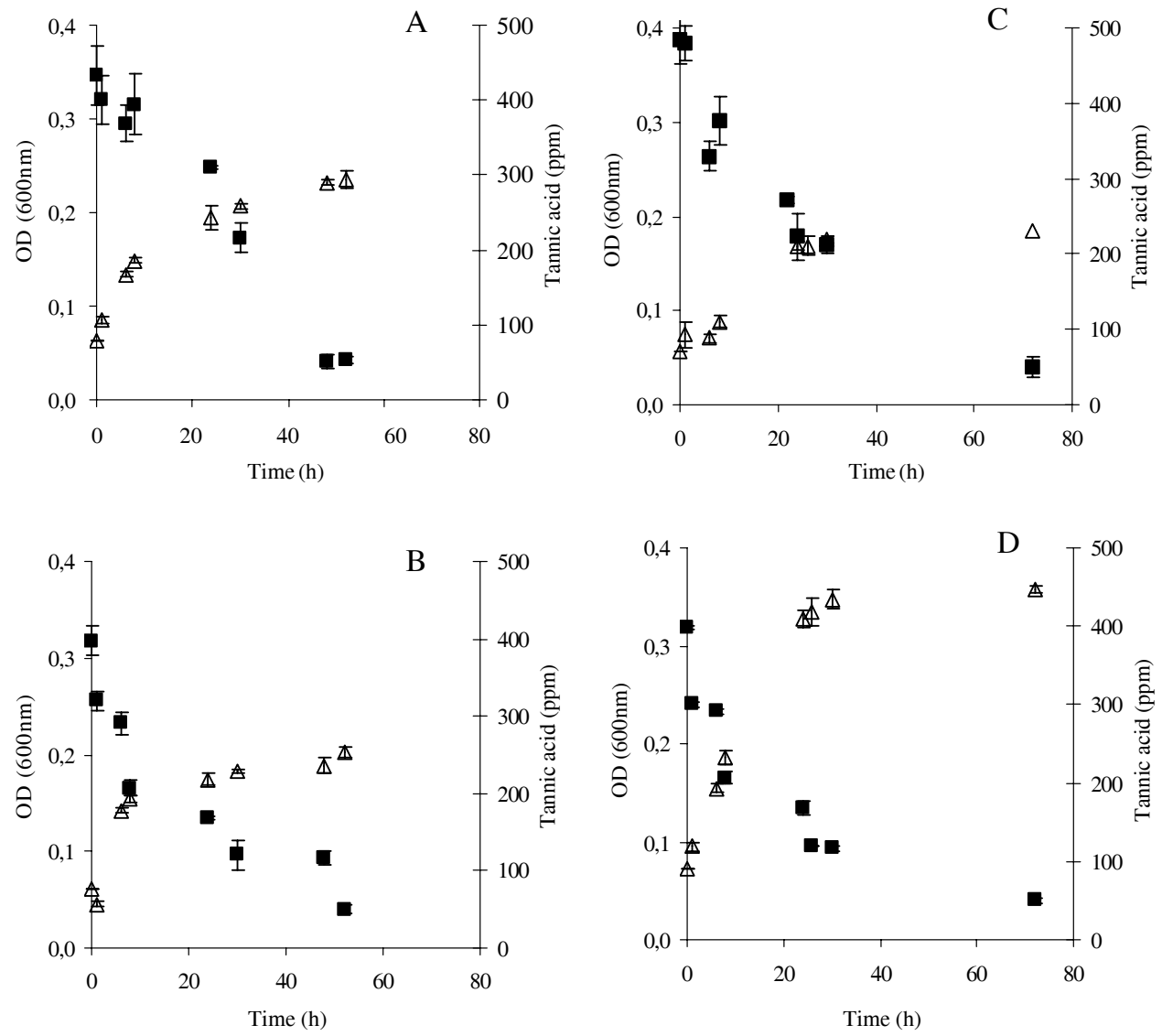

Figure 1. Growth of culture E (A and $\mathrm{B})$ and culture $\mathrm{T}(\mathrm{C}$ and $\mathrm{D})$ in tannic acid (A and $\mathrm{C}$ ) and Tara tannin (B and D). $(\triangle)$ OD; tannic acid concentration as measured by HPLC. 

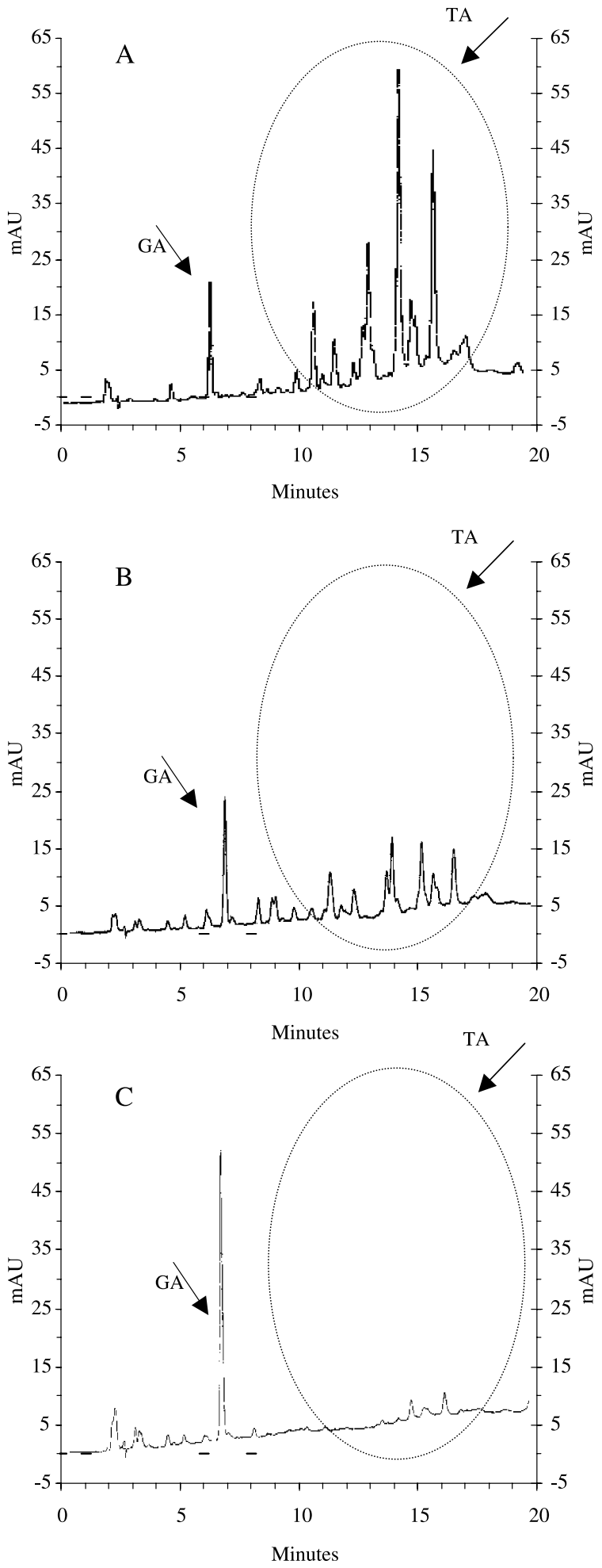

Figure 2. HPLC chromatograms of the supernatant of culture $\mathrm{T}$ grown in the presence of $0.5 \mathrm{~g} \mathrm{~L}^{-1}$ tannic acid at $0(\mathrm{~A})$, 30 (B), and $72 \mathrm{~h}(\mathrm{C})$ of incubation. Tannic acid (TA) components were eluted in the range of retention times 10.1-17.4 min and gallic acid (GA) was eluted at $6.5 \mathrm{~min}$. Arrows indicate tannic acid and gallic acid elution peaks. from enrichment culture E, and another three, CT1, CT2 and CT3, from enrichment culture T. All isolates were aerobic, Gram-negative bacteria, with a rod-shaped morphology, except CT2, which was composed of spirilla. All isolates were members of the $\gamma$ Proteobacteria. Based on 16S rDNA sequence analysis, isolate CE1 was phylogenetically most closely related to Serratia proteamaculans (99\% identity to accession number AY040208), isolate CE2 to Stenotrophomonas maltophilia (99\% identity to several strains, e.g., accession number AJ131114), isolate CE3 to various strains belonging to the genus Serratia (e.g., 97\% identity to $S$. proteomaculans, accession number AJ288155), isolate CT1 to Klebsiella oxytoca ( $97 \%$ identity to accession number AF543296), isolate CT2 to Herbaspirillum chlorophenolicum (98\% identity to accession number AB094401), and isolate CT3 to Pseudomonas putida KT2440 (99\% identity to accession number AE016774). The results obtained suggest that the isolates purified from the enrichment cultures were closely related to bacteria colonizing man-made habitats, such as sewage and polluted soils.

To investigate whether tannic acid was degraded by the bacterial isolates purified from enrichment culture $\mathrm{T}$, assays were conducted using either tannic acid or Tara tannin. After a 70-h incubation period, isolates CT1, CT2, and CT3 were able to degrade ca. $75 \%$ of tannic acid in mineral medium, indicating their ability to use that polyphenol as a single carbon source. Concerning the degradation of tannic acid present in Tara tannin, after the same time period, the extent of hydrolysis was 82, 97, and $63 \%$ for isolates CT1, CT2, and CT3, respectively. As observed with the enrichment cultures, HPLC analysis showed the accumulation of gallic acid as a degradation product. Bacterial isolates CT2 and CT3 produced, respectively, 96 and $75 \%$ of the quantity of gallic acid that could be expected, considering the stoichiometric hydrolysis of tannic acid available in Tara tannin. Strain CT1 seemed to degrade gallic acid after tannic acid hydrolysis, as indicated by HPLC (data not shown). However, this was only observed when Tara tannin was used as substrate. When using analyticalgrade tannic acid as carbon source, bacterial isolates CT1, CT2, and CT3 produced 74,78 , and $89 \%$, respectively, of the quantity of gallic acid that could be expected, considering the stoichiometric hydrolysis of tannic acid.

Biodegradation of polyphenols is often reported as being a slow process. Nevertheless, polyphenol-degrading bacteria have been reported over the last decade. For example, bacteria belonging to the genera Klebsiella, Achromobacter, Bacillus, and Streptococcus have been reported to degrade polyphenols as a sole carbon source $[12,17]$. More recently, other studies have reported the degradation of polyphenols by bacterial strains isolated from sewage. Strains belonging to the species $P$. putida, 
as isolate CT3, have been reported as able to break down and degrade condensed and hydrolyzable tannins, either as a tannin mixture or as a pure compound [17]. Genera to which the other isolates of this study belong have been reported as plant endophytes or pathogens (e.g., Herbaspirillum sp., CT2) or as belonging to the microbial soil community (like Serratia sp., CT1) [14].

\section{Conclusion}

The understanding of microbial activity in plant rhizosphere and root interior in contaminated soils is important when developing phytoremediation technologies. The enumeration of the culturable bacterial groups from a tannery discharge place showed a predominance of the aerobic bacterial group in the rhizosphere or root interior of the colonizing plants. Although other important bacterial groups (such as denitrifying and sulfate-reducing bacteria) were enumerated, the results presented here do not let us infer on their significance to the rhizosphere of the site studied. The degradation of hydrolyzable polyphenols (such as tannic acid or Tara tannin) was achieved by aerobic bacteria obtained through enrichment techniques, using soil collected from the tannery discharge site. This study is a contribution to a clearer understanding of polyphenol biodegradation in man-impacted environments.

\section{Acknowledgments}

The authors thank Dias Ruivo, Curtumes e Produtos Industriais, Lda, Vila Nova de Gaia, Portugal. This work was supported by Fundação para a Ciência e Tecnologia, Projecto-POCTI/CTA/39111/01, through research grants to Ma. Cristina S.C.C. Menezes and Albina Franco.

\section{References}

1. Altschul, SF, Gish, W, Miller, W, Myers, EW, Lipman, DJ (1990) Basic local alignment search tool. J Mol Biol 215: 403-410

2. Ayed, L, Hamdi, M (2002) Culture conditions of tannase production by Lactobacillus plantarum. Biotechnol Lett 24: 1763-1765

3. Bhat, TK, Singh, B, Sharma, OP (1998) Microbial degradation of tannins-a current perspective. Biodegradation 9: 343-357

4. Brix, H (1997) Do macrophytes play a role in constructed treatment wetlands? Water Sci Technol 35: 11-17

5. Caldeira, M, Heald, SC, Carvalho, MF, Bull, AT, Vasconcelos, I, Castro, PML (1999) 4-Chlorophenol degradation by a bacterial consortium: development of a granular activated carbon biofilm reactor. Appl Microbiol Biotechnol 52: 722-729

6. Covington, AD (1997) Modern tanning chemistry. Chem Soc Rev 26: $111-126$

7. Dunfield, KE, Germida, JJ (2001) Diversity of bacterial communities in the rhizosphere and root interior of field-grown genetically modified Brassica napus. FEMS Microbiol Ecol 38: 1-9
8. Duran, M, Padilla, B, Fiestas Ros de Ursinos, A, Mendoza, A (1991) Biodegradación de los compuestos fenólicos presentes en el alpechin. Grasas Aceites 42: 271-276

9. Grayston, SJ, Griffith, GS, Mawdsley, JL, Campbell, CD, Bardgett, RD (2001) Accounting for variability in soil microbial communities of temperate upland grassland ecosystems. Soil Biol Biochem 33: $533-551$

10. Greenberg, AE, Trussel, RR (1999) Standard Methods for the Examination of Water and Wastewater, 20th ed. American Water Works Association, Baltimore

11. Ibekwe, AM, Grieve, CM, Lyon, SR (2003) Characterization of microbial communities and composition in constructed dairy wetland wastewater effluent. Appl Environ Microbiol 69: 5060-5069

12. Kumar, RA, Gunasekaran, P, Lakshmanan, M (1999) Biodegradation of tannic acid by Citrobacter freundii isolated from a tannery effluent. J Basic Microbiol 39: 161-168

13. Modal, KC, Pati, BR (2000) Studies on the extracellular tannase from newly isolated Bacillus licheniformis KBR 6. J Basic Microbiol 40: $223-232$

14. Misko, AL, Germida, JJ (2002) Taxonomic and functional diversity of pseudomonads isolated from the roots of field-grown canola. FEMS Microbiol Ecol 42: 399-407

15. Nakamura, Y, Tsuji, S, Tonogai, Y (2003) Method for analysis of tannic acid and its metabolites in biological samples: application to tannic acid in the rat. J Agric Food Chem 51: 331-339

16. Nelson, KA, Schofield, P, Zinder, S (1995) Isolation and characterization of an anaerobic ruminal bacterium capable of degrading hydrolase tannins. Appl Environ Microbiol 61: 3293-3298

17. Pilai, BVS, Swarup, S (2002) Elucidation of the flavonoid catabolism pathway in Pseudomonas putida PML2 by comparative metabolic profiling. Appl Environ Microbiol 68: 143-151

18. Rhee, SK, Lee, GM, Yoon, JH, Park, YH, Bae, HS, Lee, ST (1997) Anaerobic and aerobic degradation of pyridine by a newly isolated denitrifying bacterium. Appl Environ Microbiol 63: 2578-2585

19. Smit, E, Leeflang, P, Gommans, S, Broek, JVD, Mil, SV, Wernars, K (2001) Diversity and seasonal fluctuations of the dominant members of the bacterial soil community in a wheat filed as determined by cultivation and molecular methods. Appl Environ Microbiol 67: 2284-2291

20. Smith, A, Imlay, JA, Mackie, RI (2003) Increasing the oxidative stress response allows Escherichia coli to overcome inhibitory effects of condensed tannins. Appl Environ Microbiol 69: 3406-3411

21. Stottmeister, U, Wiebner, A, Kuschk, P, Kappelmeyer, U, Kastner, O, Bederski, O, Muller, RA, Moormann, RA (2003) Effects of plants and microorganisms in constructed wetlands for wastewater treatment. Biotechnol Adv 22: 93-117

22. Sung, L, Munster, CL, Rhykerd, R, Drew, MC, Corapcioglu, MY (2003) The use of vegetation to remediate soil freshly contaminated by recalcitrant contaminants. Water Res 37: 2408-2418

23. Tanner, CC (1996) Plants for constructed wetland treatment systems - a comparison of the growth and nutrient uptake of eight emergent species. Ecol Eng 7: 9-83

24. Weber, S, Stubner, S, Conrad, R (2001) Bacterial populations colonizing and degrading rice straw in anoxic paddy soil. Appl Environ Microbiol 67: 1318-1327

25. Widdel, F, Bak, F (1992) Gram-negative mesophilic sulfatereducing bacteria. In: Balows, A, Truper, HG, Dworkin, W, Harder, W, Schleifer, KH (Eds.) The Prokaryotes, 2nd ed. Springer, Berlin Heidelberg New York, pp 3352-3378

26. Zhu, J, Ng, J, Filippich, LJ (1992) Determination of tannic acid and its phenolic metabolites in biological fluids by high-performance liquid chromatography. J Chromatogr 577: 77-85 